\title{
A Study of Life Satisfaction and Mood States of Police and Civil Employees
}

\author{
Dr. Atul Pawar*
}

\section{ABSTRACT:}

There are number of Psychological researches related to behavioral aspects of human being of organizational field. Presents research is about police and local body Administration of organizational field. To study police Employees psychologically become necessary because of suicide case on Duty, Demolishing, antisocial activities, aggressiveness of seniors and these results in indicate imbalance of low order. Exploitation of citizens treating inferiorly, job in satisfaction, Corruption, various scandals, sexual Harassment by some civil employees of local body administration, force to study psychologically above said is to focus on mood states of employees and life satisfaction. It is necessary to study their state of mind psychologically. Thus researcher selected the Aurangabad area of Maharashtra region in India. 400 respondents from police and civil employees were selected by random method with criterion of equal matching method. There are four hypotheses were formulated, a) The level of life satisfaction would be high in civil employees than policeman. b) The life satisfaction will be more in urban employees than rural employees serving in police and civil departments. c) There will be significant differences in mood states of police and civil employees. d) There would be significant differences in mood states of urban and rural employees serving in police and civil depts. Researcher has used life satisfaction scale designed and prepared by Q.G. Alam \& Dr. Ramji Srivastava and Mood States Questionnaire by Dr. M. Bhargva and Dr. Kapoor has used for data collection. Two-way ANOVA was applying for data analysis, all results were significant on 0.05 and 0.01 level. Hence it concluded that nature of employment and area of residence are influence on life satisfaction and mood states.

Keywords: Life Satisfaction, Mood States

\section{INTRODUCTION}

There are number of Psychological researches related to behavioral aspects of human being of organizational field. Presents research is about police and local body Administration of organizational field. Now a day's police and civil Employees are stress. Job in said employees can be seen due to nature of work, Overload, deviation from family and collogues.

*Department of Psychology, Deogiri College, Auranagabad. (M.S)

(C) 2014, A Pawar; licensee IJIP. This is an Open Access Research distributed under the terms of the Creative Commons Attribution License (http://creativecommons.org/licenses/by/2.0), which permits unrestricted use, distribution, and reproduction in any Medium, provided the original work is properly cited. 
Employees are facing Psychological problems and Emotional stability and problems and emotional stability and problem are increasing day by day low salary and job insecurity is becoming a serious problems and attitude of Employees is changing and less life satisfaction seen. Number of police and civil Employees force to study their Psychological problems/perspectives. To study police Employees Psychologically become necessary because of suicide case on Duty, Demolishing, antisocial activities, aggressiveness of seniors and this results in indicate imbalance of low order. Exploitation of citizens treating inferiorly, job in satisfaction, Corruption, various scandals, sexual Harassment by some civil employees of local body administration, force to study Psychologically Above said is to focus on mood states of employees and life satisfaction. It is necessary to study their state of mind psychologically.

\section{A) Term of life satisfaction:-}

Satisfaction is state of mind. It is an evaluative appraisal of satisfaction. The term refers to both "contentment" and "enjoyment" as such it covers cognitive as well as effective appraisal. Satisfaction can be both evanescent and stable through time

\section{Definition:-}

"Life satisfaction is the degree to which a person positively evaluates the overall quality of his lher life as a whole. In other words, how much the person likes the life he/she leads". Current synonyms for the life satisfaction are "happiness" and "subjective well being" one advantage in using the life satisfaction than word "happiness" is that it emphasis's the subjective character of the concept, the word "happiness" is also used to refer to an objective good; especially by philosophers, further, the term life satisfaction has the advantage over the label of "subjective well-being" is that life rather than to current feelings or to specific Psychosomatic symptoms.

Life satisfaction can be defined as the cognitive component of subjective well-being(Martikainen, 2008). This is consistent with Bradley \& Corwyn (2004) who say that life satisfaction reflects both the extent to which basic needs are met and the extent to which avariety of other goals are viewed as attainable. From this perspective it seems only reasonable that by accomplishing more goals, satisfaction with life will also increase. According to Beutell (2006) it is believed that life satisfaction is related to better physical, and mental health, longevity, and other outcomes that are considered positive in nature. In addition, Chow (2009) argues that improved levels of life satisfaction might give rise to better health in the future, and that this can already be identified within a three-year timeframe. Although there is a lack of congruence regarding the definition of life satisfaction (Iverson \& Maguire,2000), this thesis will adopt the definition as described by Veenhoven (1991, p.3): "Life satisfaction is conceived as the degree to which an individual judges the overall quality of his life-as-a-whole favourably.

\section{Demographic Variable as a predictor of life satisfaction :-}

The most majority of research on life satisfaction instigates the extent to which various Demographic Variable as a predict of life satisfaction. However, Because researcher are not able to perform true experiments by randomly assigning participants to demographic group( e.g. Gender, Income, Age), All of this research as necessarily been comparative much of the nature of working place \& nature of employment has focused on the determinants of life satisfaction- That is the extent to which satisfaction is related to the environment both imposed (e.g. Urban \& rural, Civil \& Police) \& relatively controllable (e.g. Income, Education, Age, Marriage, Gender)As well as to specific aspects of persons state of mind. 
Work related conditions - employment status:

Clark \& Oswald (1994) say that the effect of being jobless, at any conventional level,is statistically significant and negatively correlated with well-being. They state: "Joblessness depresses wellbeing more than any other single characteristic (including important negative ones such as divorce and separation)." Besides the loss of income, Darity \& Goldsmith (1996)argue that joblessness also leads to decreased self-esteem and a reduced feeling that life isunder control. Additionally, they say that joblessness is related to the loss of several by-products of participating in a work environment, such as: the time structure of the working day, shared experiences and contacts, transcending goals and purposes, and personal status and identity. According to Winkelman \& Winkelman (1998) these non-pecuniary costs of unemployment by far exceed the pecuniary cost associated with loss of income while being unemployed. They say that sevenfold of income is required to compensate for the negative effects associated with personal unemployment. Although it is, based on the relative standards theory, often suggested that living in a region characterized by high unemployment will alleviate the discontent of personal joblessness, Pittau, Zelli \& Gelman (2009), who examined this premise, did not find any empirical evidence for this effect.It is, alternatively, more than likely that life satisfaction is positively affected by being employed. According to Bouazzaoui \& Mullet (2002) employment is one of the requisites for satisfaction with life in Western societies. Additionally, Waddell \& Burton (2006) indicate that there is a strong theoretical case that work and paid employment are generally beneficial for physical and mental health, as well as for well-being. They argue that employment is generally the most important means of obtaining adequate economic resources, which are essential for material well-being, and full participation in today's society. Moreover, they state that work is central to individual identity, social roles and social status, and meets important psychological needs in societies where employment is the norm. Since this reasoning depicts employment as key to increasing material well-being as well as satisfying psychological needs, it is, based on the theory of post-materialism, feasible that being employed will generally have a greater impact on individuals living in economically deprived regions than on individuals residing in economically prosperous regions.

\section{B) Mood states:-}

The most recent development in scientific psychology have been concerned with the psychology of emotions. The emotional life was considered better than the rational life because it was directly connected with the body. Those theorists of antiquity and feeling at all as psychological problems attributed them to a lower type of soul. The whole direction of our schooling in ethical problems and problems of correct behavior has been, until very recently, schooling in emotional inhabitation. The child must learn to control his loves and his hates, his fears and rages, his moods of excitement and depression despite the fact that civilization requires emotional control and emotional inhabitation most of us who are honest with ourselves realize that, were it not for the promise of certain emotional satisfaction. Life would be scarcely worth living at all.

No doubt many points in the older views regarding emotions were basically sound. It is quite obvious to everyone that, must be curbed at sometimes and redirected at others. The modern view breaks with the order pre scientific view not at all another question of ethics but rather and questions as to the nature of the emotions. Emotions are today considered as natural phenomenon exactly as worthy of psychological study as any other form of behavior. 
As the age grow young and old both may regress to infancy, to escape reality, becoming depended on others for care. Thus the emotional disturbances such as anxiety, depression, aggression, conflict, fatigue at quilt feeling, among peoples may be seen commonly in several cases.

Main purpose of present study, researcher has comprises the life satisfaction and mood states to nature of employment and area of working place of police and civil employees in Aurangabad district (M.S, India).

\section{PROBLEM:-}

"To comparative study of mood states and life satisfaction of employees serving in police and civil department with reference in Marathwada region (A study limited to Aurangabad district)"

\section{OBJECTIVES:-}

Following are the main objectives of the present research study:-

1. To study the mood states of employees serving in police and civil departments.

2. To study the satisfaction of employees serving in police and civil departments.

3. To study the life satisfaction of rural and urban employees serving in police and civil Departments.

4. To study the mood states of urban and rural employees serving in police and civil departments.

\section{HYPOTHESES:-}

Following hypotheses are framed for the present study:-

1. The level of life satisfaction would be high in civil employees than policeman.

2. The life satisfaction will be more in urban employees than rural employees serving in police and civil departments.

3. There will be significant differences in mood states of police and civil employees.

4. There would be significant differences in mood states of urban and rural employees serving in police and civil depts.

\section{METHODOLOGY:-}

\section{A) Sample:-}

The sample was drawn from the population of employees working from Aurangabad district. The present study consists 400 respondents (200 policemen and 200 civil employees). Respondents were selected from Aurangabad district by Randomized method. All these respondents were matched for pay scale (a basic 4200 to 5700 ) educational qualification (12th to undergraduate), experience (10 to 15 year between) and age group (30 to 45 years). Sample consists of Police Head Constable (police employee) and Senior Clerks (civil employees).

Out of 400 respondents, 200 employees are serving in rural area of Aurangabad district since last five year and 200 urban employees serving area of Aurangabad city since at last five year. Sample of 
senior clerks were taken from collector office, Zillha Parishad office, Tahsil office and Panchayat samitee and policemen taken from various police station in Aurangabad district. Following table gives an idea of the sample.

\begin{tabular}{|c|l|l|l|}
\hline Area of working place & $\begin{array}{l}\text { Police employees (Head } \\
\text { constable) }\end{array}$ & $\begin{array}{l}\text { Civil employees } \\
\text { (Senior clerk) }\end{array}$ & Total \\
\hline Urban employees & 100 & 100 & 200 \\
\hline Rural employees & 100 & 100 & 200 \\
\hline Total & 200 & 200 & 400 \\
\hline
\end{tabular}

*Operational definitions of the terms used in the sample*.

1. Civil employees:-

Persons serving as senior clerk in Zillha Parishad, Panchayat Samitee, Tahsil office, and collector office are considered as civil employees.

2. Police Employees :-

Persons serving as head constables in police department of Aurangabad district are considered as police employees.

3. Urban employees :-

Employees serving in Aurangabad city, are considered urban employees.

4. Rural employees :

Employees serving at taluka place in Aurangabad city, are considered urban employees.

\section{B) Tools for using to data collection:-}

1. Life satisfaction scale (L-S scale):- Researcher has used life satisfaction scale designed and prepared by Q.G. Alam \& Dr. Ramji Srivastava. Published on 2001 by National psychological corporation, Agra. The L.S.S. comprises of 60 items related to six areas of life viz. Health, Personal, Economic, Marital, Social and Job. The responses are to given in yes/no. yes responses indicate Satisfaction, whereas No indicate Dissatisfaction. Test-Retest reliability quotient is 0.84 . The validity of the scale was obtained by correlating it with Saxena's Adjustment Inventory and Srivastaava adjustment inventory. The quotient obtained was 0.74 and 0.84 respectively.

2. Mood States Questionnaire by Dr. M. Bhargva and Dr. Kapoor:- Researcher has used eight state questionnaire designed and prepared by Cattell and Curran (designed 1973 Curran in press) published by National Psychological Corporation at Agra. The eight state questionnaire (8 


\section{A Study of Life Satisfaction and Mood States of Police and Civil Employees}

SQ) was specify for measuring eight important emotional states and moods i.e Anxiety, Stress, Depression, Guilt, Regression, Fatigue, Extraversion and Arousal. Reliability and Validity is very high and satisfactory of this questionnaire.

\section{C) Variables the under study:}

The present study was designed to find out the effect of independent variable and dependant variables. Following variables were studying:-

Independent variable(Ivs):-

1. Nature of Employment (A):- A1 Police Employees

\section{A2 Civil Employees}

2. Area of working place(B):- B1 Urban Employees

\section{B2 Rural Employee}

Dependent variable(Dvs):-

1. Life satisfaction

2.Mood States

D) Research design:-

In the present study researcher designed to study the Police employees and Civil employees. This was belonging from Urban and rural areas. Therefore researchers framing the following type of $2 * 2$ factorial design.

\begin{tabular}{|l|l|l|}
\hline \multirow{2}{*}{ Nature of Employment (A) } & \multicolumn{2}{|l|}{ Area of working place(B) } \\
\cline { 2 - 3 } & Urban (B1) & Rural (B2) \\
\hline Police employees(A1) & A1B1 & A1B1 \\
\hline Civil employees (A2) & & A2B2 \\
\hline
\end{tabular}

\section{E) Procedure:-}

After establishing proper rapport with the subject, the Life satisfaction Scale and Eight State Questionnaire was administered on the sample in small groups of 20-25 employees in Aurangabad district. 


\section{STATISTICAL ANALYSIS AND RESULTS:-}

Researcher apply following properties for statistical treatment, descriptive statistics, two-way ANOVA and ' $t$ ' techniques will be used for data analysis to understand the mean difference between both groups of employees.

Table no: 1 shows the research design with sample size.

\begin{tabular}{|l|l|l|}
\hline Variables(Ivs) & Value Label & N \\
\hline Area of working & Urban employees & 200 \\
\cline { 2 - 3 } & Rural employees & 200 \\
\hline \multirow{2}{*}{ Nature of Employment } & Police employees & 200 \\
\cline { 2 - 3 } & Civil Employees & 200 \\
\hline
\end{tabular}

Table No.2: Shows two-way univariate analysis of variance for dependent variable life satisfaction.

\begin{tabular}{|c|c|c|c|c|c|c|}
\hline Source & \begin{tabular}{|l|} 
Type III \\
Sum of \\
Squares
\end{tabular} & Df & $\begin{array}{l}\text { Mean } \\
\text { Square }\end{array}$ & $\mathrm{F}$ & Sig. & $\begin{array}{l}\text { Partial Eta } \\
\text { Squared }\end{array}$ \\
\hline Area of working & 4.410 & 1 & 4.410 & .197 & $\mathrm{NS}$ & -- \\
\hline $\begin{array}{l}\text { Nature of } \\
\text { Employment }\end{array}$ & 761.760 & 1 & 761.760 & 33.975 & 0.01 & .079 \\
\hline $\begin{array}{l}\text { Area of working } \mathrm{X} \\
\text { Nature of } \\
\text { Employment }\end{array}$ & 4.840 & 1 & 4.840 & .216 & NS & -- \\
\hline Error & 8878.740 & 396 & 22.421 & & & \\
\hline Corrected Total & 9649.75 & 396 & & & & \\
\hline Total & 552082.00 & 400 & & & & \\
\hline
\end{tabular}

$0.05=3.86 \quad 0.01=6.70$ 
Eta squared $=0.01=$ small effect; $0.06=$ moderate effect $0.14=$ large effect $($ Cohen, 1988$)$

In the above table two-way univariate analysis of variance it is shown that the first main effect of area of working i.e urban and rural. The value $\mathrm{F}(1,396)=0.197$ which is not significant. Hence it indicates that urban and rural employees not showing the difference about life satisfaction and no question of effect size.

Second main effect is nature of employment i.e police and civil employees the $\mathrm{F}(\mathrm{df}=1,396)$ value is 33.975, Which is significant on 0.01 level. Hence police and civil employees show significant difference in terms of their life satisfaction. Here eta squared value is 0.079 and it shows moderate effect and variance is 7.9. The interaction effect showing no significant difference about life satisfaction, "F" value is 0.216 .

For search out the difference between two means, researcher analyzed Post-Hoc test as " $\mathrm{t}$ " test.

Table No.3: shows difference between civil and police employees for dependent variable life satisfaction.

\begin{tabular}{|c|c|c|c|c|c|}
\hline Group & $\mathrm{N}$ & Mean & SD & $\mathrm{T}$ & $\begin{array}{l}\text { Significance } \\
\text { Level }\end{array}$ \\
\hline Civil & 200 & 38.21 & 4.622 & \multirow{2}{*}{5.862} & \multirow[b]{2}{*}{0.01} \\
\hline Police & 200 & 35.44 & 4.827 & & \\
\hline Urban & 200 & 36.93 & 4.996 & \multirow{2}{*}{0.4265} & \multirow{2}{*}{$\begin{array}{l}\text { Not } \\
\text { Significant }\end{array}$} \\
\hline Rural & 200 & 36.72 & \begin{tabular}{|l}
4.849 \\
\end{tabular} & & \\
\hline
\end{tabular}

$$
\mathrm{P}=0.05=1.98 \quad 0.01=2.617
$$

In the above table the mean value of civil employee is 38.21 and SD is 4.622 as well as the mean value of police employee is 35.44 and $\mathrm{SD}$ is 4.827 . Obtained ' $\mathrm{t}$ ' value is 5.862 which is significant on 0.01 level. On the basis of mean it is concluded that police employees having less life satisfaction than civil employees. And accepts first hypothesis, "The level of Life Satisfaction would be high in civil employees than Policemen". The mean value of urban employee is 36.93 and SD is 4.996 as well as the mean value of rural employee is 36.72 and SD is 4.849 . Obtained ' $t$ ' value is 0.4265 which is not significant. Hence, it is concluded that there is no difference between urban and rural employees in terms of their life satisfaction. And reject second hypothesis. "The Life Satisfaction will be more in urban employees than rural employees serving in police and civil department". 
A Study of Life Satisfaction and Mood States of Police and Civil Employees

Table No.04: shows two-way unvaried analysis of variance for dependent variable Mood states.

\begin{tabular}{|c|c|c|c|c|c|c|}
\hline Source & $\begin{array}{l}\text { Type III Sum } \\
\text { of Squares }\end{array}$ & Df & Mean Square & $\mathrm{F}$ & Sig. & $\begin{array}{l}\text { Partial Eta } \\
\text { Squared }\end{array}$ \\
\hline Area of working & 10475.523 & 1 & 10475.523 & 52.621 & 0.01 & 0.117 \\
\hline $\begin{array}{l}\text { Nature of } \\
\text { Employment }\end{array}$ & 1975.802 & 1 & 1975.802 & 9.925 & 0.01 & 0.024 \\
\hline $\begin{array}{l}\text { Area of working } \\
\text { X Nature of } \\
\text { Employment }\end{array}$ & 1517.103 & 1 & 1517.103 & 7.621 & 0.01 & 0.019 \\
\hline Error & 78833.970 & 396 & 199.076 & & & \\
\hline & 92802.4 & 396 & & & & \\
\hline Total & 3392293.000 & 400 & & & & \\
\hline
\end{tabular}

Eta squared $=0.01=$ small effect; $0.06=$ moderate effect $0.14=$ large effect

In the above table two-way unvariate analysis of variance it is shown that the first main effect of area of working i.e urban and rural .The value $F(1,396)=52.621$. which is significant on 0.01 level Hence it indicate that urban and rural employees showing significant difference about mood states and Eta squared value is 0.117 , showing moderate effect and variance is' 1.1 '.

Second main effect is nature of employment i.e police and civil employees the value $F(1,396)=$ is $9.925(\mathrm{df}=1,396)$. Which is significant on 0.01 level. Hence showing significant difference about mood states and Eta squared value is 0.024, Showing small effect and variance is'0.2.

The interaction effect showing significant difference about mood states " $F$ " value is 7.621 its significant on 0.01 level and eta squared value is 0.019 showing small effect and its variance is 0.1 .

For the critical analysis, researcher analyzed Post-Hoc test as " $t$ " test. 
Table No.5: shows difference between civil and police employees for dependent variable mood states.

\begin{tabular}{|c|c|c|c|c|c|}
\hline Group & $\mathrm{N}$ & Mean & SD & $\mathrm{T}$ & $\begin{array}{l}\text { Significance } \\
\text { Level }\end{array}$ \\
\hline Civil & 200 & 93.04 & 15.623 & \multirow[b]{2}{*}{2.9403} & \multirow[b]{2}{*}{0.01} \\
\hline Police & 200 & 88.60 & 14.572 & & \\
\hline Urban & 200 & 95.94 & 12.294 & \multirow{2}{*}{7.1130} & \multirow{2}{*}{0.01} \\
\hline Rural & 200 & 85.71 & 16.204 & & \\
\hline
\end{tabular}

$$
\mathrm{P}=0.05=1.98 \quad 0.01=2.617
$$

In the above table the mean value of civil employee is 88.60 and SD is 14.572 as well as the mean value of police employee is 93.04 and SD is 15.623 . Obtained ' $t$ ' value is 2.9403 . Which is significant on 0.01 level. On the basis of mean it is concluded that the level mood states high in police employees than civil employees. And accept third hypothesis "There will be significant differences in mood states of police and civil employees". The mean value of urban employee is 95.94 and SD is 12.294 as well as the mean value of rural employee is 85.71 and $\mathrm{SD}$ is 16.204 . Obtained't' value is 7.11 . Which is significant on 0.01 level. Hence, it is concluded that the mood states level high in rural employees and urban employees. And accepts hypothesis fourth, There would be significant differences in mood states of urban and rural employees serving in police and civil depts.

\section{DISCUSSION:-}

\section{Hypothesis No:-1}

"The level of life satisfaction would be high in civil employees than policemen"

Table No. 2 and 3 indicate mean values of life satisfaction, ' $F$ ' values and 't' values. Means of life satisfaction score are 38.21 and 35.44 respectively for civil and police employees. Civil employees' scoring is higher than policemen. The main effect of nature of employment is significant $(\mathrm{F}=33.975$, df-1, $396 \mathrm{P}<0.01)$ and ' $\mathrm{t}$ ' values $5.56<0.01$. Thus there is a significant difference in life satisfaction of police and civil employees. The results support hypothesis stating that 'The level of life satisfaction would be high in civil employees than policemen. The effect size (partial et square) for main effect of nature of employment on life satisfaction is moderate (0.079), meaning that employment explains $0.7 \%$ variance for life satisfaction (Table No. 3 ) 
The results of present study are consistent with the findings of McGinnis (1985a 1985b) who reported that lower ranked police constables were less satisfied than departmental clerks. Cooper and McGinnis $(1982,1985 a)$ showed that police constables were less satisfied with their work and life. The results are also in line with the findings of Hart-peter ( 1999) who showed significant differences in life satisfaction between police and other employees.

According to Fredric Anseel and Filip lievers ( 2007 ) favorable feedback environment is necessary for higher level of satisfaction but in police department, however, unfavorable feedback environment prevails, Hence, the policemen might experience less satisfaction than civil employees.

Moreover, there is different work culture in police services. The nature of work and life style of policemen is quite different from civil employees. They have minimum holidays, no prescribed time limit for duties. As a results, they do not enjoy personal or family life in a real sense, on the contrary, the civil employees have maximum holidays, specific duty hours, generally experience democratic way of functioning in the offices. Hence, the policemen experience more stress and less life satisfaction than civil employees.

\section{Hypothesis No. 2}

"The Life satisfaction would be more in urban employees than rural employees."

The results of the present study (Table No.2) show that the main effect of working is not significant $(\mathrm{F}=0.197$, df- $1,396 . \mathrm{P}>0.05)$ As per table 3, the means of life satisfaction scores are 36.93 and 36.72 respectively, for the urban and rural employees. The difference between the means is almost null. Thus hypothesis no. 2 is rejected.

Majority of studies have reported differences in life satisfaction for urban and rural employees. However, researcher did not find any differences in the life satisfaction of urban and rural employees. Daniela Andren, Peter Martinson(2006) who showed that life satisfaction increases with housing standard, health status, economic situation, education, trusting other people and living country side, which are the characteristics of urban areas. Hence life satisfaction is lower in western countries. Robert W. Rice (1986) suggested that the level of life satisfaction is lower in rural employees than urban employees. Margaret Peril(1984) showed that the standard of living achieved and job income are most important factors in satisfaction with the quality of urban life. Ariela Lowenstenin (2005) who showed that life satisfaction was higher in urban than rural peoples. 
In the of Indian society day by day, the difference between urban and rural area is reducing. Villagers also try to adopt urban life style. Rural people are also benefited by recent technology. Government provides same facilities all the employees in urban and rural areas. Hence no difference was observed in life satisfaction of rural and urban employees.

\section{Hypothesis No. 03}

"There will be significant differences in mood states of police and civil employees."

As per table No 4 and 5, the means of mood states score are 93.04 and 88.60 respectively for the police and civil employees, the main effect of employment (table 39) is significant for mood states $(\mathrm{F}=9.925$, df-1,396, $\mathrm{P}<0.01)$. The policemen scored higher on mood states than civil employees, the results supported hypothesis 19 . The effect size (partial eta square) for the main effect of nature of employment on mood states is small (0.024) meaning that nature of employment explains $0.2 \%$ variance for mood states. The results of indicate that the mood states levels is higher in policemen than civil employees.

Police employees have high mood state level than civil employees. In present research the mixed results are found in the term of stress, Anxiety, arousal and fatigue. But difference found in life satisfaction is effectiveness on mood states. In short there is interrelationship between work/job factors psycho-social factors end may be because of these above results are founds.

\section{Hypothesis No. 04}

There would be significant differences in mood states of urban and rural employees.

As per table 4 and 5, the mean of mood states scores are 95.94 and 85.71 respectively for the rural and urban employees. The main effect of area of working (table 39) is significant ( $\mathrm{F}=52.621$, $\mathrm{df}=1,396, \mathrm{P}<0.01)$ for mood states. The rural employees mean scored higher on mood states level than urban employees. The results support hypothesis 20. The effect size (partial eta square) for the main effect of area of working on mood states is large (0.11), meaning that area of working explains $1.1 \%$ variance for mood states. The results indicate that the mood states levels is higher in rural employee than urban employees. The mood states level is found to be more in rural employees than urban employees. From the different view of thinking mental stress is emerged. If the working place is far way from head office then the orders and information of senior officers are not cleared. The orders and information of senior officer are unclear because of for distance between working place and head office. Hence employees get pressured shed work. The job distribution is beyond capacity of the employees due to which pressure of job is increased. Having the lack of facilities, job status is getting decreased. The fulfill needs of family, salary is not 
sufficient as compare to job. Always not only due to economical problem but also work responsibility, the employees are getting seek or hectic.

\section{CONCLUSIONS:-}

On the basis of data and discussion of results, the hypotheses were tested and verified some of them were retained and some were rejected, following conclusion were drawn:

1. The civil employees having more life satisfaction than policemen.

2. The level of life satisfaction is higher in rural employees than urban employees.

3. The mood states level is higher in policemen than civil employees.

4. The mood states level is more in rural employees than urban employees.

\section{Suggestion:-}

Following attempts are made to help employee's better manage the personality:-

Design of programs and activities to increase officer participation in decision making and improve the quality of work life through enhanced communication, Development of training programs in stress awareness, Establishment of specific police stress programs such as psychological services health/ nutrition programs and exercise programs, Development of peer-counseling programs, Development of operational policies that are directed at reducing stress (scheduling, work hours, workload etc), Development of managerial skills that are people oriented, Use of relaxation and other stress reducing techniques, Use of spouse/family/involvement programs, Implementation of total wellness (physical and emotional) programs, Recognize attempt to assess, and meet the needs of diverse publics, Communicate policies effectively to publics and officers, Treat all citizens with respect and preserve human dignity, Values are designed as beliefs and principles by which the people department fulfills responsibilities, To increase the quality of life at work place, Decreasing working hours, workload and Govt. give to optimum values of work.

\section{Limitations:-}

1. The present study is limited to mainly police employees, who are serving in as of head constable and civil employees, who are serving in as senior clerks from the local administration sector.

2. The study has been delimited with respect to sample. The size of the sample is drawn from the various Police-stations in the Aurangabad city and taluka place.

3. The age group of the sample is in between 25 to 45 years \& all over is married. 


\section{A Study of Life Satisfaction and Mood States of Police and Civil Employees}

4. There is no consideration for sex difference in the present research.

5. Present study is only limited on Aurangabad District.

\section{REFERENCES:-}

1. Beutell, N. (2006). References \& Research: Life Satisfaction (2006). Retrieved January 15, 2009, from the World Wide Web:

http://wfnetwork.bc.edu/encyclopedia_entry.php?id=3283.

2. Chow, R. (2009). Happiness and Life Satisfaction Lead to Better Health. Retrieved April 9,2009 from the World Wide Web: http://www.naturalnews.com/025352.htm

3. Iverson, R.D \& Maguire, C. (2000). The Relationship between Job and Life Satisfaction: Evidence from a Remote Mining Community. Human Relations 53(6), 807-839

4. Martikainen, L. (2008). The Many Faces of Life Satisfaction among Finnish Young Adults.

5. Journal of Happiness Studies. DOI 10.1007/s10902-008-9117-2.

6. Veenhoven, R. (1991). Questions on Happiness: Classical Topics, Modern Answers, and Blind Spots. In Stack, F., Argyle, M. \& Schwartz, N. (Eds.), Subjective Well-Being: An Interdisciplinary Perspective (pp. 1-26). Elmsford, New York: Pergamon Press. 